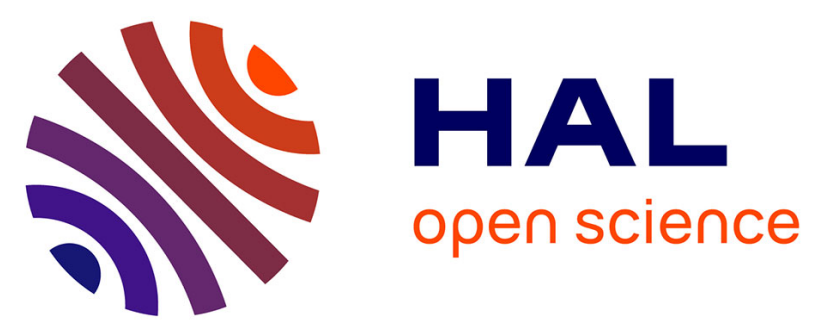

\title{
GPS measurements of crustal deformation in the Baikal-Mongolia area (1994-2002) : Implications for current kinematics of Asia
}

E. Calais, M. Vergnolle, V. San'Kov, A. Lukhnev, A. Miroshnitchenko, S. Amarjargal, Jacques Déverchère

\section{To cite this version:}

E. Calais, M. Vergnolle, V. San'Kov, A. Lukhnev, A. Miroshnitchenko, et al.. GPS measurements of crustal deformation in the Baikal-Mongolia area (1994-2002): Implications for current kinematics of Asia. Journal of Geophysical Research, 2003, 108 (B10), pp.ETG 14-1. 10.1029/2002JB002373 . hal-00406988

\section{HAL Id: hal-00406988 \\ https://hal.science/hal-00406988}

Submitted on 29 Jan 2021

HAL is a multi-disciplinary open access archive for the deposit and dissemination of scientific research documents, whether they are published or not. The documents may come from teaching and research institutions in France or abroad, or from public or private research centers.
L'archive ouverte pluridisciplinaire HAL, est destinée au dépôt et à la diffusion de documents scientifiques de niveau recherche, publiés ou non, émanant des établissements d'enseignement et de recherche français ou étrangers, des laboratoires publics ou privés. 


\section{GPS measurements of crustal deformation in the Baikal-Mongolia area (1994-2002): Implications for current kinematics of Asia}

Eric Calais, ${ }^{1}$ Mathilde Vergnolle, ${ }^{2}$ Vladimir San'kov, ${ }^{3}$ Andrei Lukhnev, ${ }^{3}$
Andrei Miroshnitchenko, ${ }^{3}$ Sharavyn Amarjargal, ${ }^{4}$ and Jacques Déverchère ${ }^{5}$
Received 27 December 2002; revised 5 May 2003; accepted 14 May 2003; published 25 October 2003.

[1] We present new geodetic results of crustal velocities over a large part of northern Asia based on GPS measurements in the Baikal rift zone and Mongolia spanning the 19942002 period. We combine our results with the GPS velocity field for China of Wang et al. [2001] and derive a consistent velocity field for most of Asia. We find contrasted kinematic and strain regimes in Mongolia, with northward velocities and N-S shortening in westernmost Mongolia but eastward to southeastward motion and left-lateral shear for central and eastern Mongolia. This eastward to southeastward motion of central and eastern Mongolia is accommodated by left-lateral slip on the E-W trending Tunka, Bolnay, and Gobi Altay faults $\left(2 \pm 1.2 \mathrm{~mm} \mathrm{yr}^{-1}, 2.6 \pm 1.0 \mathrm{~mm} \mathrm{yr}^{-1}\right.$, and $1.2 \mathrm{~mm} \mathrm{yr}^{-1}$, respectively) and by about $4 \mathrm{~mm} \mathrm{yr}^{-1}$ of extension across the Baikal rift zone. Consequently, $\sim 15 \%$ of the India-Eurasia convergence is accommodated north of the Tien Shan, by N-S shortening combined with dextral shear in the Mongolian Altay and by eastward displacements along major left-lateral strike-slip faults in central and eastern Mongolia. We find a counterclockwise rotation of north and south China as a quasi-rigid block around a pole north of the Stanovoy belt, which rules out the existence of an Amurian plate as previously defined and implies $<2 \mathrm{~mm} \mathrm{yr}^{-1}$ of left-lateral slip on the Qinling Shan fault zone. INDEX TERMS: 1208 Geodesy and Gravity: Crustal movements -intraplate (8110); 1244 Geodesy and Gravity: Standards and absolute measurements; 8107 Tectonophysics: Continental neotectonics; 9320 Information Related to Geographic Region: Asia; KEYWORDS: continental deformation, active faults, GPS, Mongolia, Baikal, Asia

Citation: Calais, E., M. Vergnolle, V. San'kov, A. Lukhnev, A. Miroshnitchenko, S. Amarjargal, and J. Déverchère, GPS measurements of crustal deformation in the Baikal-Mongolia area (1994-2002): Implications for current kinematics of Asia, J. Geophys. Res., 108(B10), 2501, doi:10.1029/2002JB002373, 2003.

\section{Introduction}

[2] The ability of plate tectonics concepts to describe deformation of large continental areas like Asia or the western United States is subject to much debate. End-member models assume that continents deform either by rigid motion of lithospheric blocks along narrow fault zones or by viscous flow as continuously deforming solids. Discriminating these end-member models requires spatially dense measurements of surface strain rates covering the whole deforming area, including areas outside the obvious active faults and plate boundary zones.

\footnotetext{
${ }^{1}$ Department of Earth and Atmospheric Sciences, Purdue University, West Lafayette, Indiana, USA.

${ }^{2}$ UMR CNRS 6526, University of Nice, Valbonne, France.

${ }^{3}$ Institute of the Earth's Crust, Siberian Branch of the Russian Academy of Sciences, Irkutsk, Russia.

${ }^{4}$ Research Center for Astronomy and Geophysics, Ulan Baatar, Mongolia.

${ }^{5}$ UMR CNRS 6538, University Bretagne Occidentale, Plouzané, France.

Copyright 2003 by the American Geophysical Union. 0148-0227/03/2002JB002373\$09.00
}

[3] Asia is the major example of present-day deformation of a large continental domain (Figure 1). Current deformation in Asia is distributed over a broad area extending from the Himalayas in the south to the Baikal rift zone in the north, with a number of rigid blocks such as the Tarim basin, south China, north China, and the Sunda block, embedded in the deforming zone. The analysis of Landsat imagery in the late 1970s [Tapponnier and Molnar, 1977, 1979] together with geologic and seismological data [e.g., Molnar and Deng, 1984; Molnar et al., 1987] led to the identification of a limited number of large strike-slip faults straddling Asia, accommodating lateral displacements of these rigid lithospheric blocks. Some of the India-Eurasia convergence is also accommodated by thrusting and crustal shortening in high topography compressional ranges such as the Himalayas, the Pamir-Tien Shan range, the Mongolian Altay, and the Gobi Altay. In addition, Asia is characterized by two broad high elevation plateaus, the Tibetan and Mongolia plateaus, with an average elevation of 5000 and $2500 \mathrm{~m}$ and crustal thicknesses up to 70 and $50 \mathrm{~km}$, respectively.

[4] It was recognized early on that intracontinental deformation in Asia was the result of the collision between India 


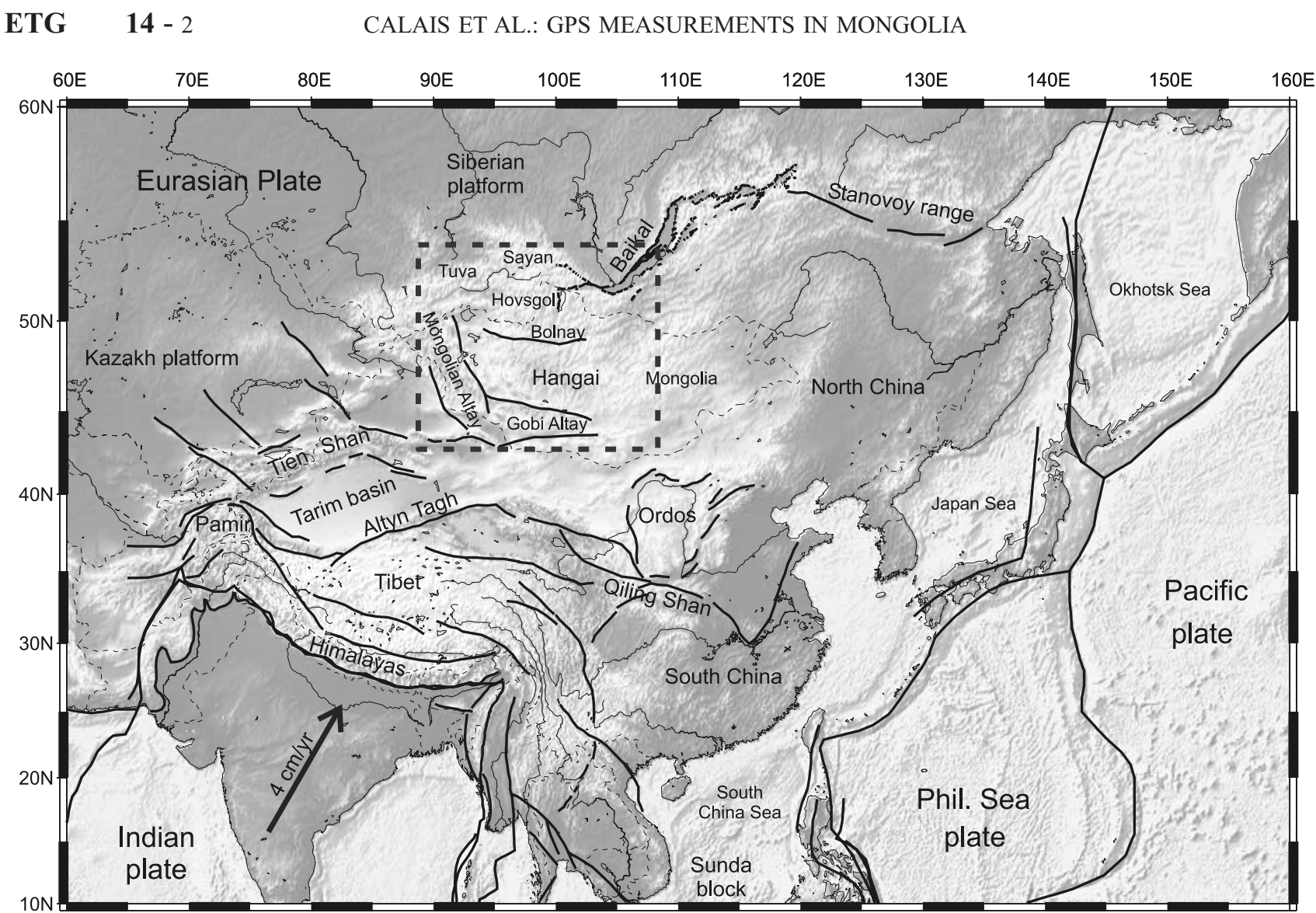

Figure 1. Topography, main active faults, and index of the geographical names used in this paper. The box centered on Mongolia shows the study area, shown in more detail on Figure 2.

and Eurasia [Argand, 1924]. Since then, a number of deformation models have been proposed to explain the available geological and geophysical data sets. "Kinematic" models propose that continental deformation occurs by eastward extrusion of lithospheric blocks of quasi-rigid behavior, bounded by lithospheric-scale strike-slip faults, in response to the India-Eurasia collision [Tapponnier et al., 1982; Peltzer and Tapponnier, 1988; Avouac and Tapponnier, 1993; Peltzer and Saucier, 1996]. In these models, continental deformation is entirely edge-driven, and continental tectonics does not differ from that of the oceans. Conversely, "dynamic" models assume that the lithosphere can be treated as a continuous viscous medium. In these models, India-Eurasia convergence is accommodated by crustal thickening, inducing lateral variations in gravitational potential energy that, in turn, drive the present-day deformation [Vilotte et al., 1982; England and Houseman, 1986; Cobbold and Davy, 1988; Houseman and England, 1986, 1993; England and Molnar, 1997]. While the advances made in modeling continental deformation in Asia during the last 20 years are impressive, each of these studies have suffered from limited data quality and quantity. The differences in the conclusions drawn might not only reflect the true complexity of deformation processes and heterogeneity of the lithosphere but also the limitations of the data sets used.

[5] The past few years have seen a rapid increase in the amount of geodetic results available in Asia [e.g., Abdrakhmatov et al., 1996; Bilham et al., 1997; King et al., 1997; Paul et al., 2001; Calais et al., 1998; Larson et al., 1999; Heki et al., 1999; Shen et al., 2000; Chen et al., 2000; Kogan et al., 2000; Calais and Amarjargal, 2000; Bendick et al., 2000; Wang et al., 2001; Calais et al., 2002]. One of the main motivations for geodetic studies is the hope to discriminate between "kinematic" deformation models, that favor the motion of rigid crustal blocks along large active faults, and "dynamic" models, that favor deformation by lithospheric thickening with a significant role of buoyancy forces rather than the extrusion of rigid crustal blocks (see discussion above). For instance, Bendick et al. [2000] claim that the $9 \mathrm{~mm} \mathrm{yr}^{-1}$ GPS-derived slip rate on the Altyn Tagh fault, together with N-S shortening of Tibet at $\sim 9 \mathrm{~mm} \mathrm{yr}^{-1}$, supports the idea of pervasive deformation and thickening of the Asian lithosphere better than extrusion models. On the other hand, the eastward velocity of south China at 8 to $10 \mathrm{~mm} \mathrm{yr}^{-1}$ measured by GPS [e.g., Larson et al., 1999; Wang et al., 2001] fits kinematic and dynamic models equally well. Therefore, even though it is now accepted that only $20-30 \%$ of the India-Eurasia convergence is accommodated by lateral extrusion of continental blocks [e.g., Molnar and Gibson, 1996; Peltzer and Saucier, 1996], no consensus has yet been reached on the processes and relative importance of the forces that drive present-day continental deformation in Asia.

[6] One of the reasons may reside in the geographical distribution of the available geodetic data, mostly concentrated in the Himalayas, Tibet, Pamir-Tien Shan, and surrounding regions (mostly south China). In contrast, the 


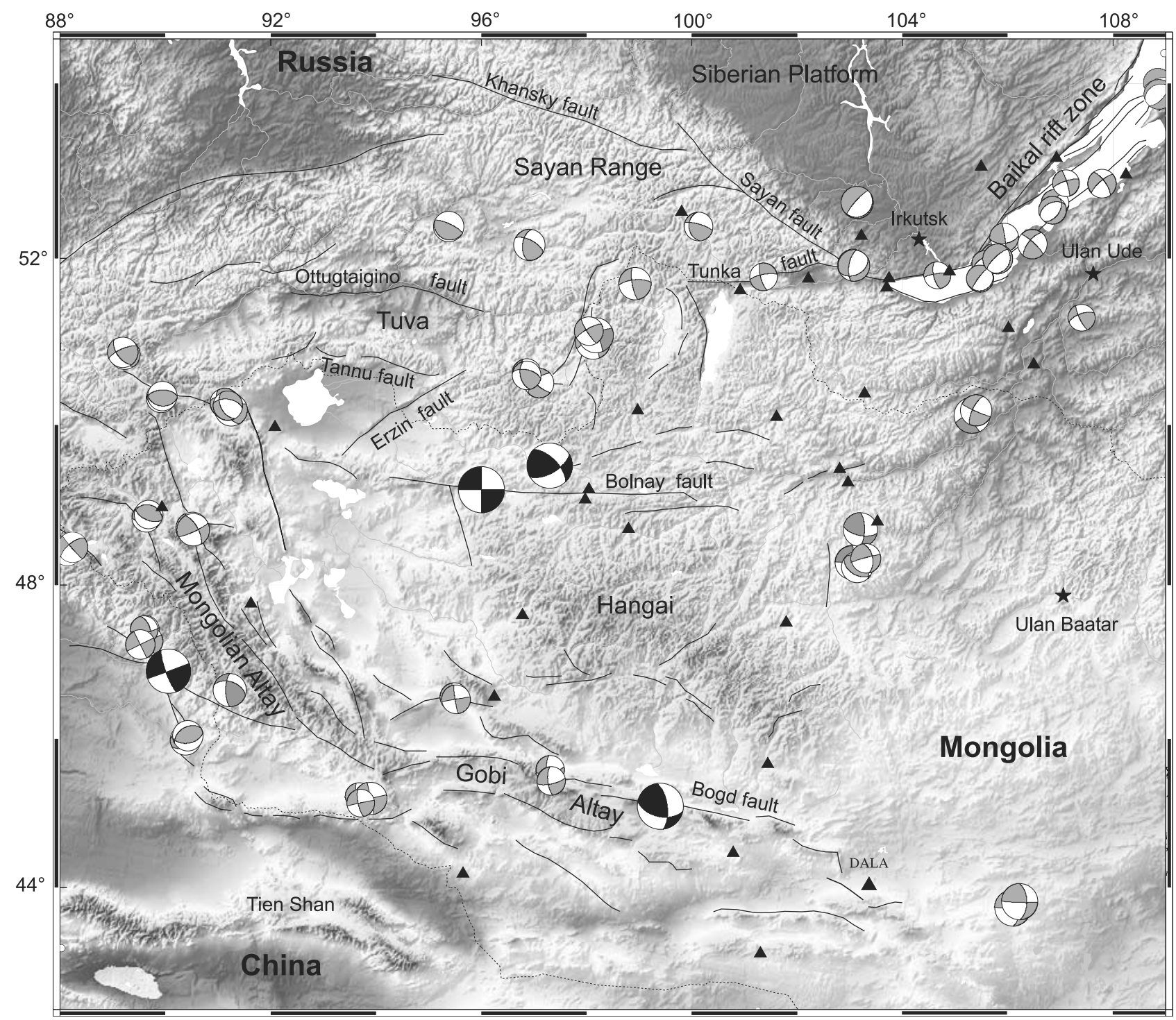

Figure 2. Topography, main active faults, and focal mechanisms of major earthquakes $(6<M<8$ in grey, $M>8$ in black) in the Mongolia-Baikal region (see location map on Figure 1). Triangles, location of campaign GPS sites; black stars, permanent GPS sites. Topography indicates strong elevation changes from the Siberian craton to the north $(\sim 450 \mathrm{~m})$ to the Hangay dome and Mongolia-Altay belt $(\sim 4500 \mathrm{~m})$.

current level of knowledge is much lower to the north in northern China, Mongolia, and southern Siberia, to a point where active deformation in these regions is sometimes assumed to be negligible or even not considered at all in the models, in spite of major active structures such as the Baikal rift zone, the Altay mountains, and M8 and greater historical earthquakes in Mongolia and the Baikal rift zone [Okal, 1977; Khilko et al., 1985; Baljinnyam et al., 1993]. As a result, intracontinental deformation in Asia is sometimes thought of as equivalent to India-Eurasia collision, even though the relative importance of the collision versus other processes (such as continental subduction, gravitational potential energy, mantle dynamics, shear traction at oceanic subductions) in the current force balance in Asia is still matter of debate.

[7] In addition, although geodetic data could potentially provide decisive constraints for discriminating deformation models and assessing the rheology of the Asian lithosphere, the available geodetic data sets suffer a number of problems. First, most solutions cover only parts of Asia. The most comprehensive solution to date [Wang et al., 2001] covers most of China but does not include the Altay area, Mongolia, and the Baikal rift zone. Moreover, the solutions published so far are expressed in significantly different reference frames and therefore cannot be readily compared. Finally, the definition of a Eurasia-fixed framework to map the velocity has proven difficult to achieve [Kogan et al., 2000; Calais and Amarjargal, 2000; Sella et al., 2002].

[8] In this paper, we present new geodetic results of crustal velocities over a large part of northern Asia in the Baikal rift zone and Mongolia based on GPS measurements spanning the 1994-2002 period (Figure 2). We put a particular emphasis on the definition of a Eurasia-fixed reference frame for mapping the GPS-derived velocities. We combine our results with recently published velocities for China [Wang et al., 2001], produce a consistent velocity 
field that covers most of Asia, and discuss its implications in terms of continental deformation in Asia.

\section{Data and Methods}

\subsection{GPS Data Processing}

[9] We began GPS measurements in July 1994 in the Baikal rift zone and in August 1997 in western Mongolia. The whole network currently consists of 44 sites, all of which have been surveyed at least three times. The measurements were made with Ashtech Z12 GPS receivers, initially equipped with Geodetic II and Geodetic III antennas, and with choke ring antennas since 1998. During each campaign, each site was usually surveyed $22-24$ hours a day for an average of three consecutive days. In addition, we incorporate GPS data from two permanent sites located inside the network: Irkutsk (IRKT), which has been operating in the framework of the International GPS Service for Geodynamics (IGS) since October 1996, and Ulan Baatar (ULA1), which operated continuously from 1995 to 2000 and has since been replaced by the ULAB IGS station. The data set contains a total of 464 site days and 1822 daily RINEX (Receiver Independent Exchange format) files.

[10] We analyze pseudorange and phase GPS data in single-day solutions using the GAMIT software (R. W. King and Y. Bock, documentation for the GAMIT GPS software analysis, release 10.1, unpublished, 2002). We solve for regional station coordinates, satellite state vectors, seven tropospheric zenith delay parameters per site and day, and phase ambiguities using doubly differenced GPS phase measurements. We use IGS final orbits, IERS Earth orientation parameters, and apply azimuth- and elevation-dependent antenna phase center models, following the tables recommended by the IGS. We include 16 global IGS stations to serve as ties with the ITRF2000 [Altamimi et al., 2002]. The least squares adjustment vector and its corresponding variance-covariance matrix for station positions and orbital elements estimated for each independent daily solution are then passed to a Kalman filter (GLOBK [Herring et al., 1990]) and combined with global SINEX (Solution Independent Exchange format) files from the IGS daily processing routinely done at Scripps Institution of Oceanography (SIO). We then impose the reference frame using this combined solution by minimizing the position and velocity deviations of IGS core stations with respect to the ITRF2000 while estimating an orientation, translation, and scale transformation. The height coordinates and vertical velocities are weighted by a factor of 10 less than the horizontal components. This estimation is based on 41 globally distributed stations, that we chose as the ones with the lowest uncertainties in position and velocity in the ITRF2000 definition. The postfit root-mean-square (RMS) of the reference frame stabilization is $2.3 \mathrm{~mm}$ in position and $0.6 \mathrm{~mm} \mathrm{yr}^{-1}$ in velocity.

[11] Our results over the eight year period 1994-2002 are listed in Table 1. The standard deviations have been computed by scaling the formal $1-\sigma$ uncertainties of the final adjustment by the overall chi-square per degree of freedom. Long-term baseline repeatabilities (weighted RMS scatter about the best fit linear regression to the position time series) are 2-4 $\mathrm{mm}$ for the horizontal components and 5-12 $\mathrm{mm}$ for the vertical component. The velocity field, described hereafter, confirms and consolidates earlier results obtained in the southern part of the Baikal rift zone and northern Mongolia using a smaller number of sites and shorter time span [Calais et al., 1998, 2002]. In addition, velocities are now available at 24 new sites in the Baikal rift zone and western Mongolia.

\subsection{Eurasia Reference Frame}

[12] We define the Eurasian plate by inverting GPS velocities at 15 sites distributed across the Eurasian plate (YAKT, IRKT, KSTU, ARTU, ZWEN, GLSV, GRAZ, WSRT, POTS, WTZR, KOSG, CAGL, NRIL, NVSK, VILL; Figure 3 and Table 2). This site distribution is similar to the one used by Kogan et al. [2000] but covers a broader area than the one used by Wang et al. [2001]. Contrary to Kogan et al. [2000] and Wang et al. [2001], we did not use KIT3, POL2, and IRKT to define the Eurasian plate because these sites are located in central Asia within $50 \mathrm{~km}$ of actively deforming areas (Tien Shan mountains and Baikal rift zone). We also avoided using stations located in areas where the contribution of glacial isostatic adjustment to horizontal velocities may be greater than $1 \mathrm{~mm} \mathrm{yr}^{-1}$ such as ONSA, NYAL, and METS [Milne et al., 2001; Sella et al., 2002]. Four of the sites chosen to define Eurasia are included in our regional solutions as well as in the global solutions downloaded from the SIO IGS analysis center (YAKT, GRAZ, NVSK, KSTU). These sites therefore benefit from the redundancy of the combination of two independent solutions.

[13] We subtract the Eurasia-ITRF2000 rotation found here from the ITRF2000 velocities in order to map our results in a Eurasia-fixed frame. The residual velocities are shown on Figure 3 for the Eurasian plate and most of Asia, and on Figure 4 for the Mongolia-Baikal area. We find significant residual velocities at POL2, KIT3, and NYAL (as well as at TROM), which justifies, a posteriori, our choice of excluding these sites from the definition of stable Eurasia. We find a systematic northwestward residual at stations located in the eastern part of the Eurasian plate (east of the Ural mountains: NVSK, KSTU, YAKT, NRIL), however close or below their associated uncertainty. We find insignificant residual velocities at IRKT and ONSA. Adding these sites to the Eurasia reference frame definition has no significant impact on the resulting Eurasia-fixed velocity field. We find no significant residual velocity at TIXI, situated on the north American plate, close to the seismically active area that marks the Eurasia/North America plate boundary [Cook et al., 1986]. This result is consistent with the location of the Eurasia/North America Euler pole derived from several geodetic studies [Kogan et al., 2000; Sella et al., 2002] found to be located close to TIXI.

\subsection{Combination}

[14] In order to obtain a consistent velocity field for Asia, we combined our results with the velocities published by Wang et al. [2001]. We used 22 continuous IGS sites common to the two data sets (GUAM, TSKB, YAKZ, TIXI, TAEJ, SUWN, TAIW, SHAO, BJFS, WUHN, XIAN, BAKO, IRKT, NTUS, KUNM, KSTU, LHAS, URUM, SELE, POL2, KIT3, ZWEN) to estimate a seven-parameter Helmert transformation between the two solutions and convert Wang et al.'s velocities from ITRF97 to ITRF2000. We did not use the vertical velocities in the estimation 
Table 1. Velocities $(V)$ With Respect to Eurasia and Associated One Standard Deviation Formal Errors $(\sigma)$

\begin{tabular}{|c|c|c|c|c|c|c|c|}
\hline Site & Longitude & Latitude & $V_{e} \mathrm{~mm} \mathrm{yr}^{-1}$ & $V_{n} \mathrm{~mm} \mathrm{yr}^{-1}$ & $\sigma_{e} \mathrm{~mm} \mathrm{yr}^{-1}$ & $\sigma_{n} \mathrm{~mm} \mathrm{yr}^{-1}$ & Correction \\
\hline ALTA & 96.25 & 46.55 & 3.9 & 2.0 & 0.4 & 0.3 & 0.039 \\
\hline ANGA & 106.58 & 52.79 & -0.9 & 1.5 & 0.5 & 0.4 & -0.001 \\
\hline ARVA & 102.79 & 46.26 & 6.1 & -0.7 & 0.9 & 0.8 & -0.067 \\
\hline ARVX & 103.02 & 46.12 & 5.2 & 1.0 & 1.0 & 0.6 & -0.045 \\
\hline BADA & 102.21 & 51.76 & 0.6 & -0.5 & 0.3 & 0.3 & -0.012 \\
\hline BATS & 110.85 & 48.52 & 1.0 & -3.5 & 0.7 & 0.5 & 0.087 \\
\hline BAYA & 105.50 & 53.06 & -2.2 & 3.0 & 0.6 & 0.6 & -0.010 \\
\hline BOL1 & 98.05 & 49.21 & 2.3 & -0.2 & 0.3 & 0.3 & 0.009 \\
\hline BOL2 & 97.98 & 49.08 & 3.0 & 1.4 & 0.4 & 0.4 & 0.004 \\
\hline BULG & 103.52 & 48.80 & 1.5 & 0.5 & 0.3 & 0.3 & -0.004 \\
\hline BZUR & 98.98 & 50.18 & 1.6 & -0.9 & 0.4 & 0.3 & -0.023 \\
\hline $\mathrm{CHOI}$ & 114.58 & 48.09 & 2.0 & -2.4 & 0.5 & 0.4 & 0.058 \\
\hline DALA & 104.43 & 43.59 & 4.8 & 1.2 & 0.3 & 0.2 & -0.015 \\
\hline ERBL & 101.61 & 50.10 & 1.4 & 2.1 & 0.3 & 0.3 & 0.001 \\
\hline ERDE & 104.22 & 49.04 & -0.3 & -2.6 & 1.4 & 1.0 & -0.017 \\
\hline HADR & 103.22 & 52.26 & -0.5 & -0.9 & 0.4 & 0.5 & 0.037 \\
\hline HARA & 102.35 & 51.60 & 0.8 & 1.0 & 1.1 & 0.9 & -0.034 \\
\hline HOVD & 91.63 & 47.76 & 2.1 & 4.7 & 0.5 & 0.3 & 0.025 \\
\hline IKUL & 98.80 & 48.71 & 2.7 & -0.1 & 0.5 & 0.3 & -0.003 \\
\hline IRKT & 104.32 & 52.22 & -0.6 & 0.3 & 0.1 & 0.1 & -0.052 \\
\hline KHAR & 100.79 & 44.47 & 3.9 & -0.1 & 0.5 & 0.4 & 0.015 \\
\hline KIAT & 106.49 & 50.74 & 1.8 & -0.6 & 0.2 & 0.2 & -0.022 \\
\hline KULT & 103.74 & 51.77 & 0.7 & 0.2 & 0.3 & 0.3 & 0.004 \\
\hline LIST & 104.89 & 51.85 & 0.1 & 2.1 & 0.3 & 0.2 & -0.041 \\
\hline MAND & 106.22 & 45.80 & 3.6 & -0.2 & 0.4 & 0.3 & -0.030 \\
\hline MOND & 100.91 & 51.62 & 0.5 & -0.4 & 0.4 & 0.3 & -0.017 \\
\hline MURN & 100.10 & 49.66 & 2.1 & 0.3 & 0.4 & 0.4 & -0.041 \\
\hline NSEL & 102.81 & 49.45 & 0.5 & 1.1 & 0.4 & 0.3 & -0.013 \\
\hline NVSK & 83.24 & 54.84 & -0.7 & 1.3 & 0.7 & 0.5 & 0.014 \\
\hline ORLK & 99.80 & 52.54 & -0.4 & 2.2 & 0.4 & 0.3 & -0.038 \\
\hline SLYU & 103.70 & 51.65 & 0.9 & 0.0 & 0.3 & 0.2 & -0.003 \\
\hline SSEL & 102.96 & 49.29 & 1.4 & 0.5 & 0.4 & 0.4 & 0.011 \\
\hline SUKG & 106.25 & 50.23 & 1.2 & -1.5 & 0.3 & 0.3 & -0.038 \\
\hline TEEG & 101.44 & 45.67 & 2.0 & -1.7 & 0.6 & 0.4 & 0.010 \\
\hline TES1 & 95.87 & 49.62 & 0.3 & 2.4 & 0.5 & 0.4 & 0.047 \\
\hline TSET & 101.80 & 47.52 & 4.3 & -1.4 & 0.5 & 0.4 & -0.011 \\
\hline TURK & 108.24 & 52.97 & 1.0 & -0.3 & 0.3 & 0.3 & -0.010 \\
\hline UDUN & 106.01 & 51.17 & 1.5 & -0.9 & 0.2 & 0.2 & -0.036 \\
\hline ULA1 & 107.05 & 47.87 & 3.7 & -1.8 & 0.3 & 0.2 & -0.011 \\
\hline ULAA & 92.08 & 49.97 & 0.8 & 2.8 & 0.4 & 0.3 & 0.032 \\
\hline ULGI & 89.94 & 48.98 & 2.1 & 4.6 & 0.5 & 0.4 & 0.032 \\
\hline ULIA & 96.78 & 47.61 & 3.6 & 0.7 & 0.5 & 0.3 & 0.018 \\
\hline UNDE & 110.59 & 47.26 & 1.8 & -0.6 & 0.6 & 0.4 & 0.071 \\
\hline UNDU & 101.31 & 43.09 & 3.2 & 0.5 & 0.5 & 0.3 & 0.017 \\
\hline URUM & 87.60 & 43.81 & 2.6 & 10.0 & 0.2 & 0.1 & -0.001 \\
\hline UZUR & 107.74 & 53.33 & -0.8 & 2.0 & 0.4 & 0.4 & 0.040 \\
\hline ZAKM & 103.28 & 50.38 & 2.5 & 0.8 & 0.5 & 0.6 & 0.060 \\
\hline
\end{tabular}

because of the large uncertainties associated with this component. The RMS of the differences at the 22 common sites between the Wang et al.'s horizontal velocities in ITRF2000 and ours is $1.1 \mathrm{~mm} \mathrm{yr}^{-1}$. The relatively good fit probably results from the fact that the transformation is based on continuous GPS stations with a long data time span in both solutions (1991-2001 from Wang et al., 1994-2002 from this work). We then converted the combined velocity field in a Eurasia-fixed frame using the ITRF2000-Eurasia rotation parameters described above. The resulting combined velocity field is shown on Figure 5. Note that we chose to discard sites that had an uncertainty larger than $1.5 \mathrm{~mm} \mathrm{yr}^{-1}$ at the $95 \%$ confidence level.

\section{Interpretation and Discussion}

\subsection{Mongolia-Baikal Area}

[15] Mongolia occupies a peculiar place in Asia (Figure 2), at the transition between a N-S convergent province to the south in the Tien Shan and a NW-SE extensional province to the north in the Baikal rift zone [e.g., Baljinnyam et al., 1993; Cunningham et al., 1996a, 1996b; Schlupp, 1997; Bayasgalan, 1999; Bayasgalan et al., 1999]. Western Mongolia is an area of high elevation (1600 m average), with contrasting topographic features (Figure 2): (1) two narrow linear belts that develop along major strike-slip faults, the Altay to the west with right-lateral motion on $\mathrm{N} 150^{\circ}$ trending strike-slip faults, the Gobi Altay to the south with left-lateral motion on $\mathrm{N} 100^{\circ}$ trending strike-slip faults; and (2) two broad dome-shaped areas of elevated relief associated with sparse Cenozoic and Quaternary volcanics and a moderate heat flow, the Hangai and Hovsgol domes. These two features are not associated with recent faulting, except for a few short normal faults in the central part of the Hangai dome and along the Hovsgol and Busingol half grabens. The Altay and Gobi Altay ranges show evidence for strike slip and shortening, but their relative amount is unknown. The current strain regime in 


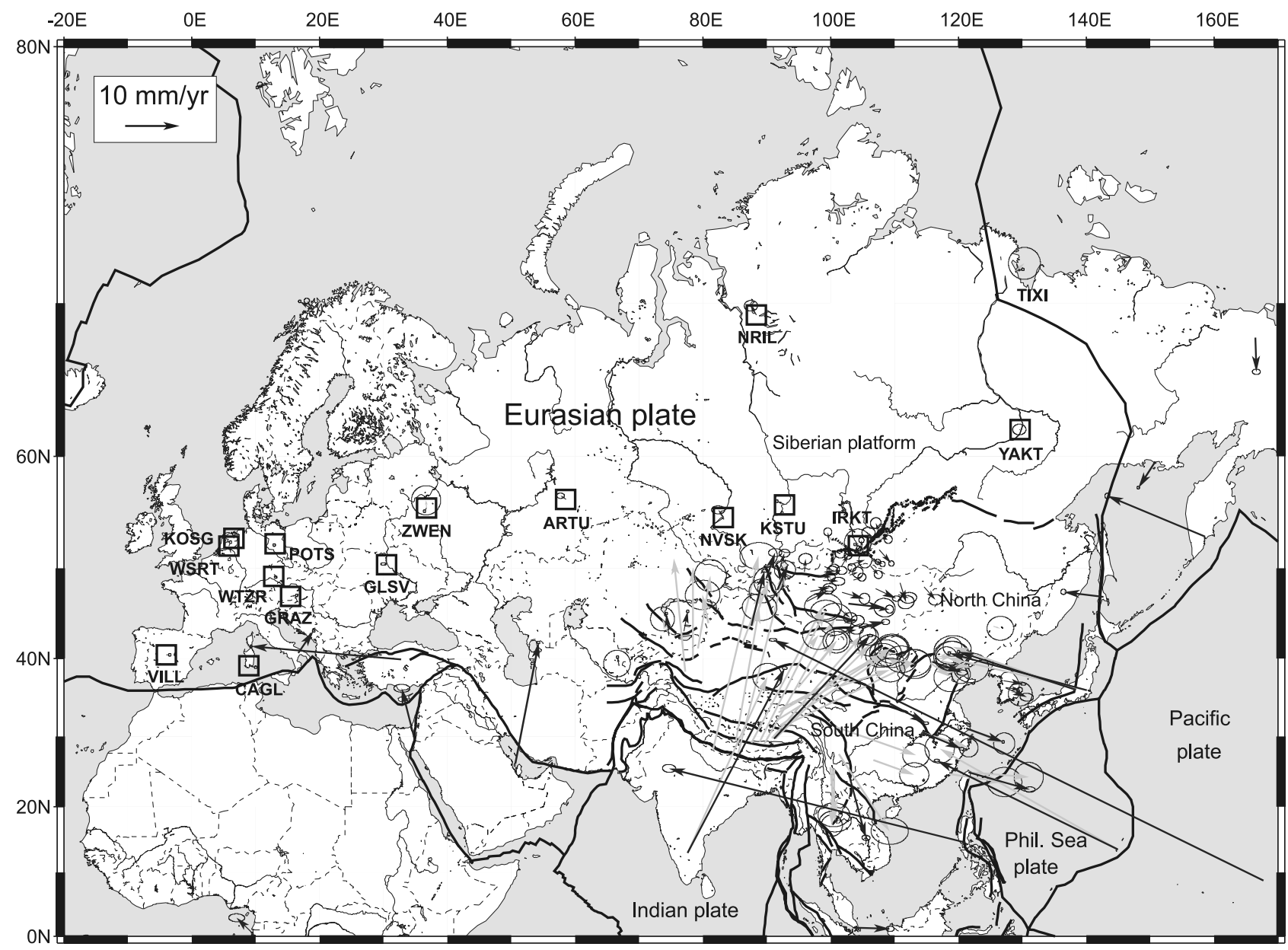

Figure 3. GPS-derived velocities with respect to Eurasia. Squares show sites used to estimate the ITRF2000-Eurasia rotation parameters. Ellipses are 95\% confidence.

Mongolia is usually inferred to be transpressional, resulting from the combination of the N-S India-Eurasia convergence and the eastward extrusion of Tibet and China [Tapponnier and Molnar, 1979].

[16] West of the Hangai and Hovsgol domes, we find velocities directed northward, with rates decreasing from south to north, from $10 \mathrm{~mm} \mathrm{yr}^{-1}$ south of the Altay at Urumqi, $\sim 4 \mathrm{~mm} \mathrm{yr}^{-1}$ in the Altay, to about zero on the Siberian platform. (Velocities discussed below are with respect to Eurasia, unless quoted otherwise.) This gradual northward decrease of velocities suggests shortening distributed over a broad area. Some of that shortening may be accommodated by right-lateral motion on NW-SE trending faults in the Altay. The velocities at ULAA and TES1 suggest that about $3 \mathrm{~mm} \mathrm{yr}^{-1}$ of shortening occurs north of western Mongolia, in the mountains of the Tuva Republic. Active deformation in the Tuva area and further east in the Sayan mountains is poorly known. However, recent geological observations along the Kansky fault on the northern border of east Sayan range (Figure 2) report reverse fault scarps affecting Quaternary lacustrine sediments, with a total throw reaching $8 \mathrm{~m}$ [Arjannikova et al., 2003]. Similar investigations along the EW trending Ottugtaigino-Azassky and south Tannu-Ola faults and the NE trending Erzin-Agardag fault (Figure 2) report post-Late Pleistocene left-lateral strike-slip motions with reverse com- ponent [Arjannikova, 2000; Parfeevets et al., 2002]. These observations are consistent with the GPS data and suggest that the Tuva-Sayan area is currently deforming, possibly under a strain regime combining N-S compression and leftlateral strike slip.

[17] One of the most striking features of the velocity field shown on Figure 4 is the sharp transition between northward velocities west of $\sim 96 \mathrm{E}$ longitude and eastward velocities east of that longitude. Using an average $\sim 5 \mathrm{~mm} \mathrm{yr}^{-1} \mathrm{NNE}$ velocity for the Altay (see sites ULGI and HOVD on Figure 4), and an average $\sim 4 \mathrm{~mm} \mathrm{yr}^{-1}$ ENE velocity for the western part of the Hangai dome (sites ALTA and ULIA on Figure 4), results in $\sim 4 \mathrm{~mm} \mathrm{yr}^{-1}$ of relative motion between the two domains, probably accommodated by right-lateral strike-slip on the NNW-SSE trending faults of the Altay range.

[18] In central Mongolia, from the Gobi Altay to the Hovsgol dome (i.e., from $96^{\circ} \mathrm{E}$ to $104^{\circ} \mathrm{E}$ ), we find velocities

Table 2. Eurasia-ITRF2000 Rotation Parameters

\begin{tabular}{lc}
\hline \multicolumn{1}{c}{ Parameter } & Value \\
\hline Plate & Eura-ITRF \\
Latitude, deg & $52.266 \pm 0.18$ \\
Latitude, deg & $-107.022 \pm 0.18$ \\
Rate, deg Myr $^{-1}$ & $0.245 \pm 0.005$ \\
\hline
\end{tabular}




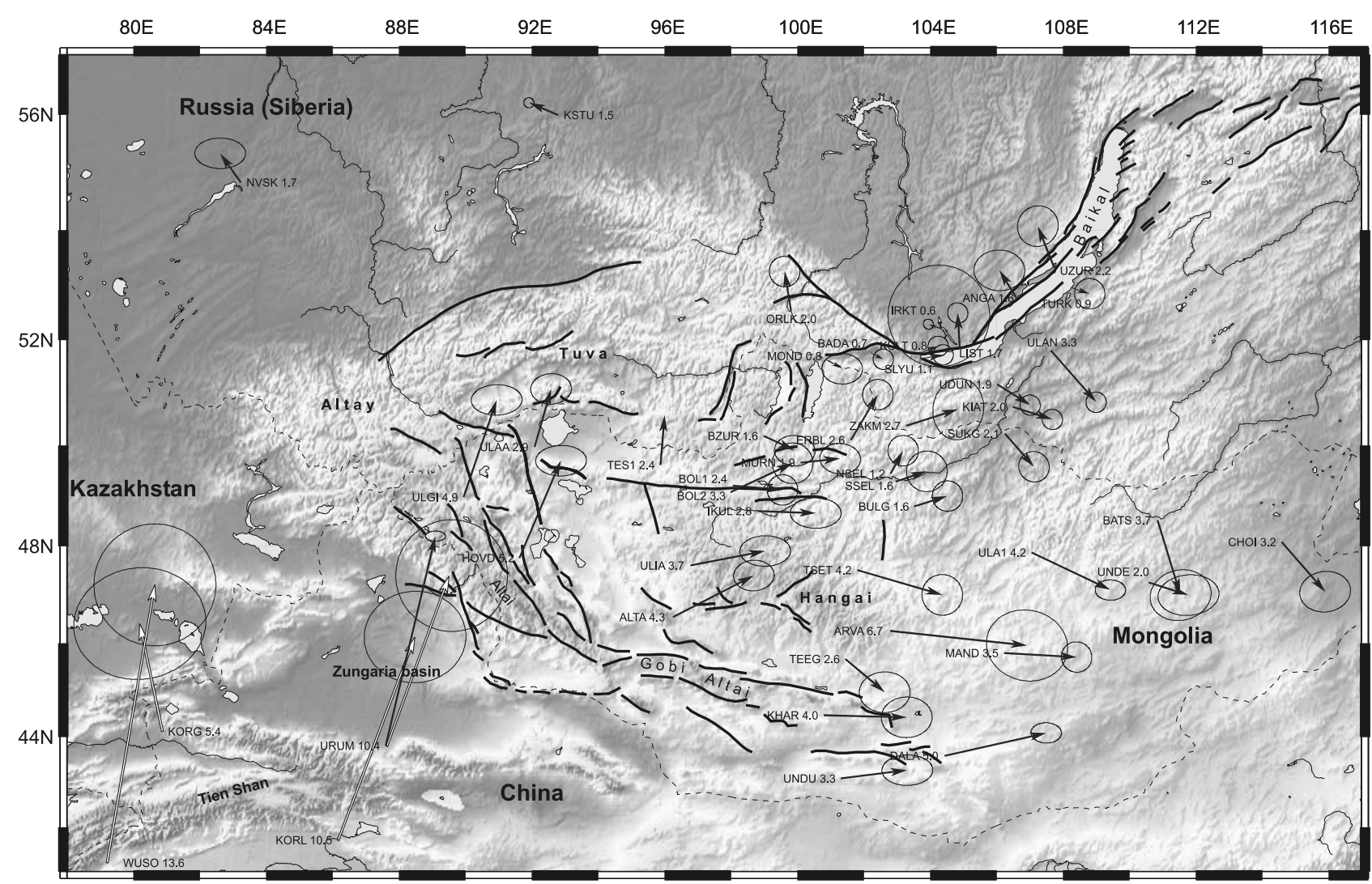

Figure 4. GPS-derived velocities with respect to Eurasia. Ellipses are 95\% confidence. Numbers by the

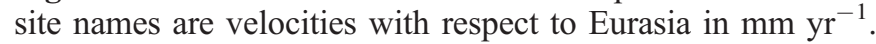

directed eastward, with the east velocity component decreasing from $\sim 4 \mathrm{~mm} \mathrm{yr}^{-1}$ in the Gobi Altay to zero on the Siberian platform. This N-S velocity gradient appears clearly in the velocity component parallel to the major strike-slip faults, whereas the fault-perpendicular component shows a larger scatter (Figure 6). This spatial fault-parallel velocity gradient suggests elastic strain accumulation on the Tunka, Bolnay, and Bogd strike-slip faults. We construct a simple deformation model that assumes elastic strain accumulation on locked faults embedded in an elastic half-space [e.g., Savage, 1983]. Faults are locked from the surface through the brittle upper crust and slip freely below that depth. Input into the model includes fault location, dip, strike, and sense of slip as constrained by geologic data [Khilko et al., 1985; Baljinnyam et al., 1993; Kurushin et al., 1997], as well as fault locking depth.

[19] The distribution of earthquakes with depth in the Baikal rift zone and Mongolia shows that most of the seismicity is concentrated between 10 and $20 \mathrm{~km}$ but that the crust is seismogenic at depths as great as $\sim 35-40 \mathrm{~km}$ [Déverchère et al., 1993; Vertlib, 1981; Bayasgalan, 1999; Déverchère et al., 2001]. For instance, Bayasgalan [1999] used waveform modeling of several recent earthquakes in western Mongolia and found that 5 out of 29 earthquakes with $m_{b}>5.0$ occurred at depths between 20 and $30 \mathrm{~km}$. These indications of a thick seismogenic crust in the western Mongolia-Baikal area are consistent with the analysis of the earthquake depth distribution in terms of rheological properties of the lithosphere, that indicates a brittle-ductile transition at about $25 \mathrm{~km}$ and a seismogenic thickness of $35 \pm 5 \mathrm{~km}$ [Déverchère et al., 2001]. We will therefore use a $35 \mathrm{~km}$ thick seismogenic depth in our models. In order to account for postseismic relaxation effects of the Bolnay and Bogd earthquakes, that are still contributing to surface deformation in Mongolia in the time period of the GPS measurements at the $1-2 \mathrm{~mm} \mathrm{yr}^{-1}$ level [Vergnolle et al., 2003], we remove the postseismic effects from the observed GPS velocities according to the best fit model of Vergnolle et al.

[20] We model the Tunka, Bolnay, and Bogd faults as pure strike-slip faults with vertical dip, as indicated by the source mechanism of the major earthquakes that occurred on these faults. An additional component of shortening may be associated with the Bogd fault [Kurushin et al., 1997]. However, including that additional reverse component did not significantly affect our results. Also, the number of GPS sites available near the Bogd fault is too small and the scatter of their fault-perpendicular velocity components too large to allow us to derive conclusions on fault-perpendicular motion at this point. We prescribe a $1.2 \mathrm{~mm} \mathrm{yr}^{-1} \mathrm{slip}$ rate on the Bogd fault, according to the average Holocene rate estimated by Ritz et al. [1995]. The slip rate on the Bolnay and Tunka faults are unknown, we estimate these two parameters by running a series of models and ranking them by their $\chi^{2}$ statistics. Figure 7 shows that the best fit is obtained with $2 \pm 1.2 \mathrm{~mm} \mathrm{yr}^{-1}$ of slip on the Tunka fault and $2.6 \pm 1.0 \mathrm{~mm} \mathrm{yr}^{-1}$ of slip on the Bolnay fault $(95 \%$ confidence). No Holocene geologic slip rates have yet been published for the Bolnay fault. Using offsets in Holocene alluvial fans along the Tunka fault, San'kov et al. [2002] 


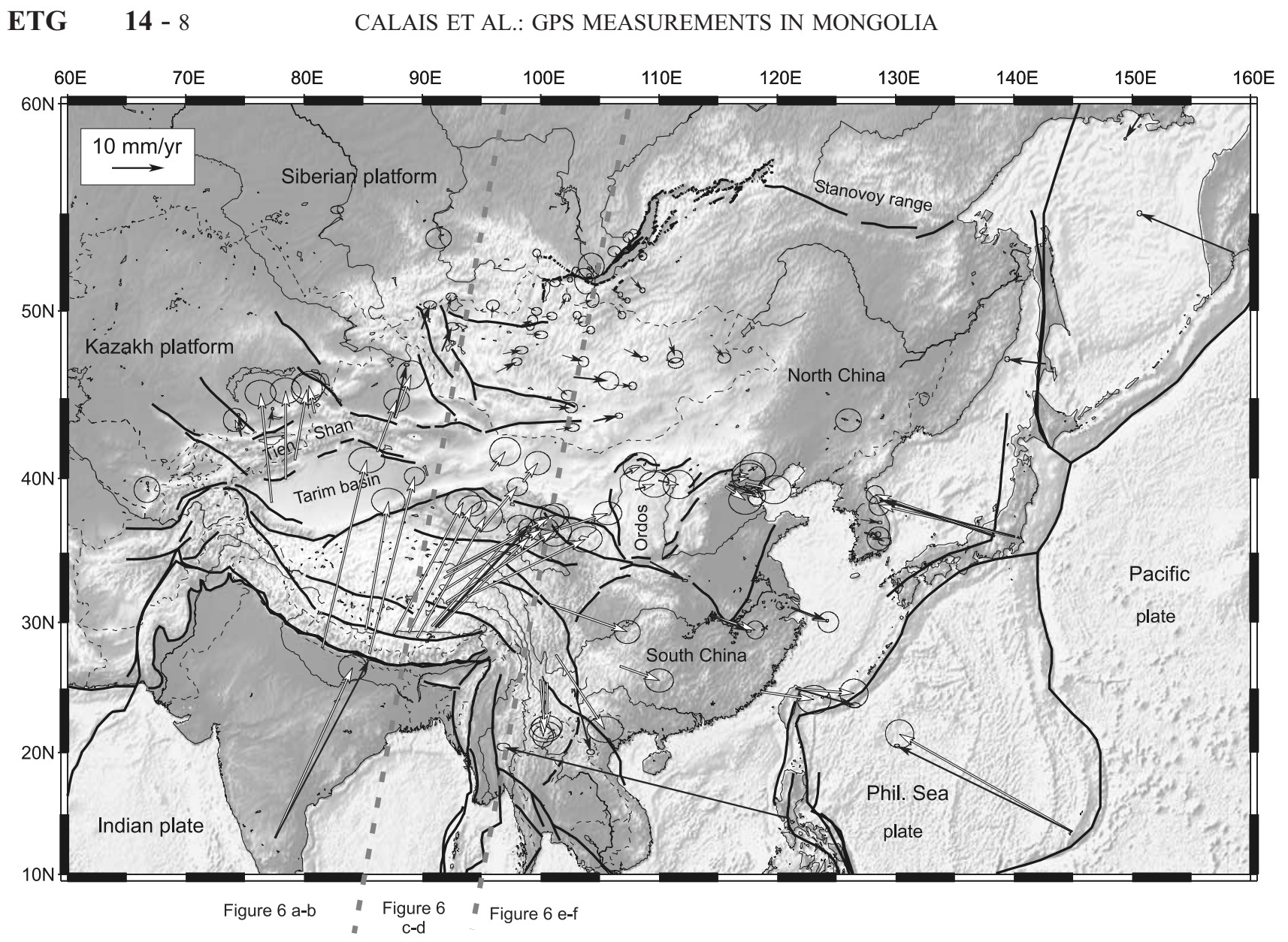

Figure 5. GPS-derived velocities with respect to Eurasia. Black arrows, our solution; white arrows, Wang et al.'s [2001] solution after transformation into ITRF2000 and rotation into a Eurasia-fixed frame (explanation in text). The grey dashed lines across the figure delineate the three domains shown on Figure 8. Ellipses are 95\% confidence.

found a minimum left-lateral slip rate of $0.86-2.5 \mathrm{~mm} \mathrm{yr}^{-1}$. Figure 6 compares the GPS data with the best fit elastic strain accumulation model. This result does not change significantly if we prescribe $0 \mathrm{~mm} \mathrm{yr}^{-1}$ of slip on the Bogd fault. Repeating this search with locking depths ranging from 10 to $55 \mathrm{~km}$ show that the lowest $\chi^{2}$ value is indeed obtained for $35 \mathrm{~km}$. These low slip rates are consistent with the long repeat time of large earthquakes on large strike-slip faults in Mongolia (3000-4000 years [Prentice et al., 2002; Ritz et al., 2003]). Also, the $5.8 \mathrm{~mm} \mathrm{yr}^{-1}$ cumulative leftlateral slip rate across central Mongolia found here is consistent with the total amount of simple shear estimated by Vergnolle et al. [2003] on the basis of an inversion of the GPS velocities that accounts for postseismic effects of the large Mongolia earthquakes.

[21] East of the Hangai dome (i.e., east of about $104^{\circ} \mathrm{E}$ ), GPS velocities are directed eastward to southeastward at

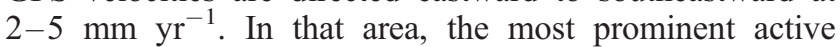
structure is the Baikal rift zone, the largest active continental rift system in Eurasia. It extends over a distance of about $2000 \mathrm{~km}$ along the S-shaped Paleozoic suture that separates the Siberian Platform to the north from the Sayan-Baikal mobile belt to the south. The GPS velocities indicate that the Baikal rift zone is currently opening at $4 \pm 1 \mathrm{~mm} \mathrm{yr}^{-1}$ (using stations IRKT, LIST, ANGA,
UZUR on its northern flank and stations TURK, ULAN, UDUN, KIAT, and SUKG on its southern flank, Figure 4). This result is in good agreement with geological estimates based on topographic offsets in Holocene alluvial fans, that indicate $3.2 \pm 0.5 \mathrm{~mm} \mathrm{yr}^{-1}$ of total extension in the northern part of the Baikal rift zone during the last 10,000 years [San'kov et al., 2002]. The direction of extension is roughly perpendicular to the direction of the major normal faults, except in the southernmost part of the rift zone, where extension is combined with left-lateral shear, as also indicated by earthquake focal mechanisms [Solonenko et al., 1997; Delvaux et al., 1997; Delouis et $a l ., 2002]$. The velocities found here south of the Baikal rift zone and in eastern Mongolia are consistent with southeastward velocities found by Shen et al. [2000] and Wang et al. [2001] at GPS sites in north China. We present hereafter a further discussion of these velocities in the broader context of crustal motions in Asia.

\subsection{Comparison With Deformation Models of Asia}

[22] The GPS velocity field on Figure 5 shows many of the most prominent features predicted by most deformation models of Asia, in particular the NNE-SSW shortening between India and the Tarim basin, accommodated in part by eastward motion of Tibet and south China and by 


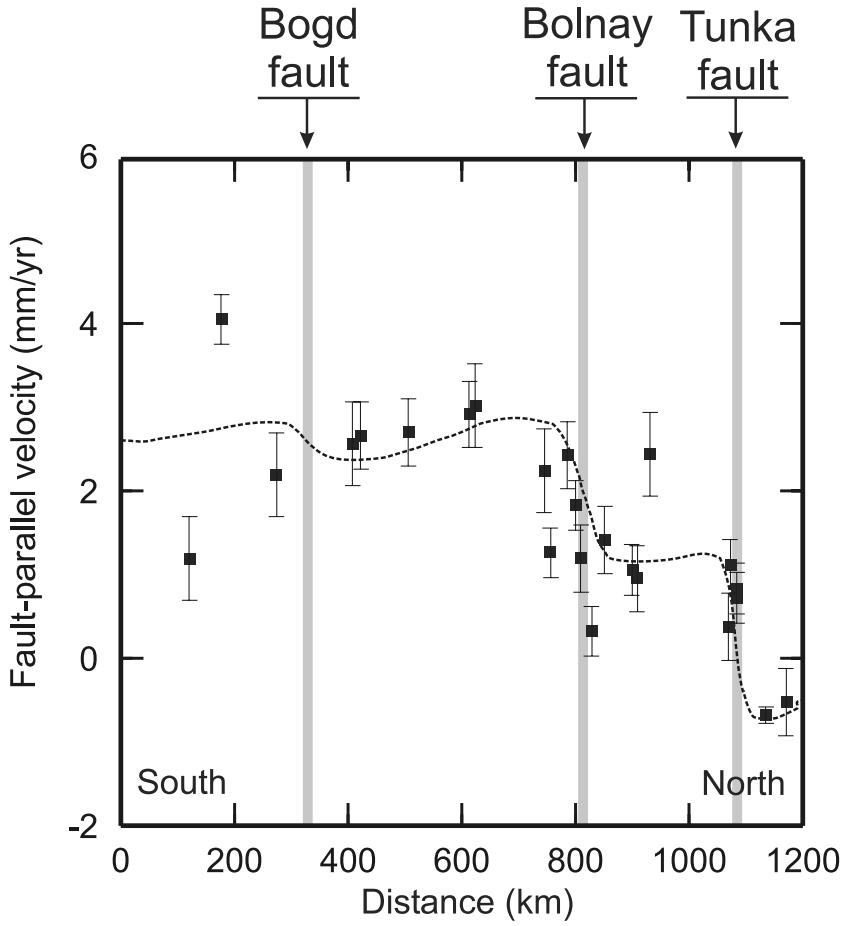

Figure 6. Fault-parallel velocities on a north-south profile across central Mongolia. Dashed line, elastic strain accumulation model, using the best fit parameters (explanations in text); squares, GPS velocity and associated 95\% confidence error bar. The grey lines indicate the location of the three faults modeled. The apparent "reverse" gradients are result of the projection.

clockwise rotation of eastern Tibet around the eastern Himalayan syntaxis, and the NNW-SSE shortening across the Tien Shan at $\sim 20 \mathrm{~mm} \mathrm{yr}^{-1}$ in the west, decreasing eastward to $\sim 10 \mathrm{~mm} \mathrm{yr}^{-1}$.

[23] Figure 8 shows a comparison between the observed GPS velocities and the kinematic model of Peltzer and Saucier [1996]. The model predicts a combination of N-S shortening north of the Indian plate (Figures 8a and 8c) and eastward velocities in Tibet and south China (Figures $8 \mathrm{~b}$ and $8 \mathrm{~d}$ ), qualitatively consistent with the GPS observations. The model rates are overestimated in the N-S component, which could simply reflect the choice of the NUVEL1A India-Eurasia convergence rate as boundary condition. Recent reevaluation of seafloor magnetic anomalies in the Indian Ocean, together with splitting Africa into a Nubian and a Somalian plate indeed reduced the India/Eurasia convergence by about 25\% [Gordon et al., 1999], consistent with the $38 \mathrm{~mm} \mathrm{yr}^{-1}$ velocity found here in southern India (Bangalore, where NUVEL-1A predicts $48 \mathrm{~mm} \mathrm{yr}^{-1}$ ). This lower angular velocity of India compared to NUVEL-1A is also supported by GPS-derived plate motion parameters for India [Paul et al., 2001; Sella et al., 2002].

[24] The observed velocity field shows in general a smooth pattern, with deformation evenly distributed over a broad area. As expected, Peltzer and Saucier's [1996] fault-bounded rigid block model shows deformation localized on single faults or in their close vicinity. This apparent disagreement requires a more detailed analysis, as it may result from a lack of spatial resolution in the GPS data and/ or to elastic strain accumulation on locked faults. For instance, the Tarim basin is known to behave largely as a rigid block, rotating clockwise with respect to Eurasia [Avouac and Tapponnier, 1993; Molnar and Ghose, 2000].

[25] A notable result of the GPS data is the absence of N-S shortening in east China, which is contrary to the model prediction on Figure 8e. Also, the GPS measurements show eastward to southeastward motions in eastern Mongolia and north China, where the model shows northeastward motions (Figures 5, 8e, and 8f). This is also quite clear for central Mongolia (Figures 8c and 8d), with GPS data showing

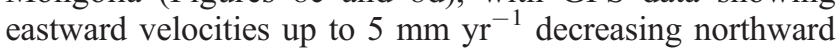
to zero (pure E-W left-lateral shear), whereas the model predicts purely northward velocities (N-S compression). Similarly, GPS results indicate that the Baikal rift zone is currently opening at $4 \pm 1 \mathrm{~mm} \mathrm{yr}^{-1}$, consistent with previous GPS results based on a shorter data time span [Calais et al., 1998], whereas Peltzer and Saucier's [1996] model predicts $0-1 \mathrm{~mm} \mathrm{yr}^{-1}$.

[26] A possible explanation for these misfits could be that extrusion models are missing a significant dynamic component of the force balance driving continental deformation in Asia and/or that their rheology is not adequate. Extrusion models assume full coupling at the India/Eurasia collision zone, zero coupling along the Pacific subductions (no shear traction), and neglect gravitational forces. England and Molnar [1997] and Flesch et al. [2001] propose that gravitational forces play a major role in the dynamics of continental deformation in Asia. Kong and Bird [1996] show that shear traction at the Pacific subductions has a significant impact on deformation over the entire Asian continent. They argue that even though subduction shear traction may be low (less than $1 \mathrm{MPa}$ ), it will result in a

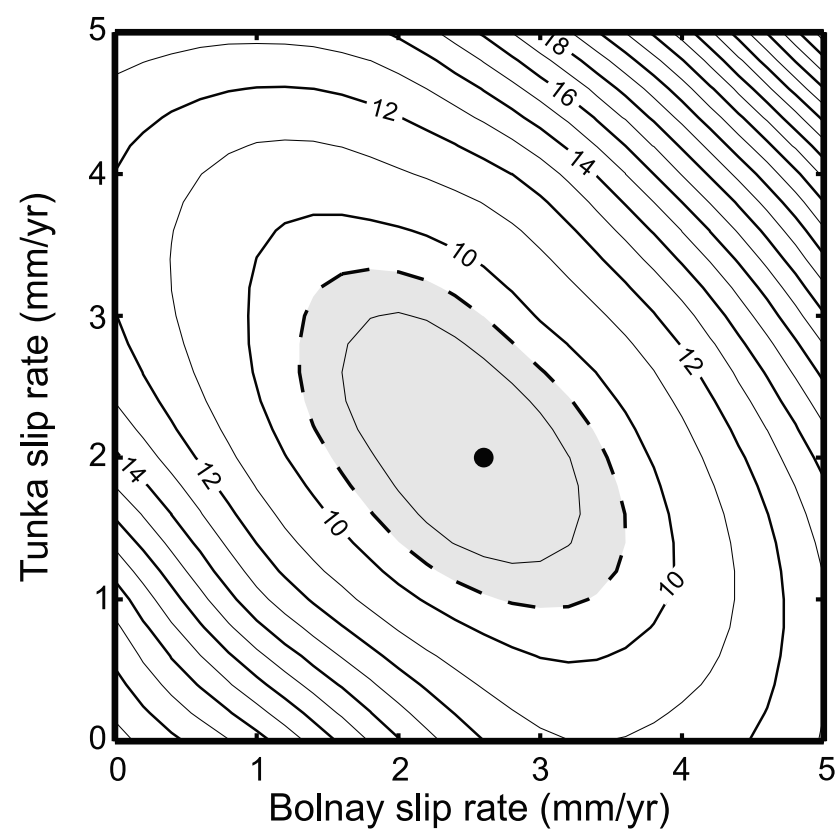

Figure 7. Contour plots of the $\chi_{r}^{2}$ statistic for the Bolnay fault versus Tunka fault slip rates. The dashed line is the boundary of the $95 \%$ confidence area. 


\section{W-Mongolia profile}
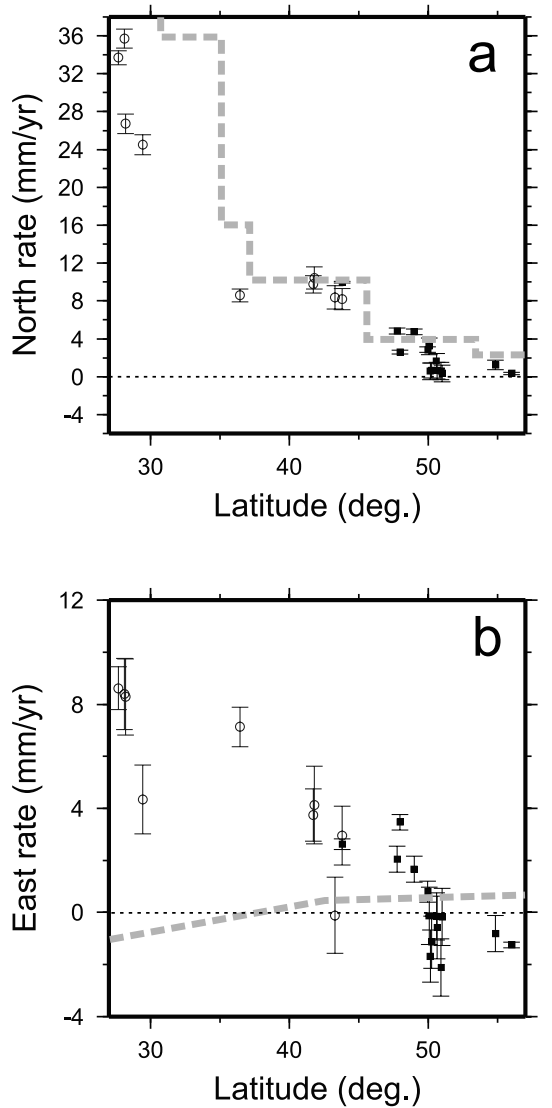

C-mongolia profile
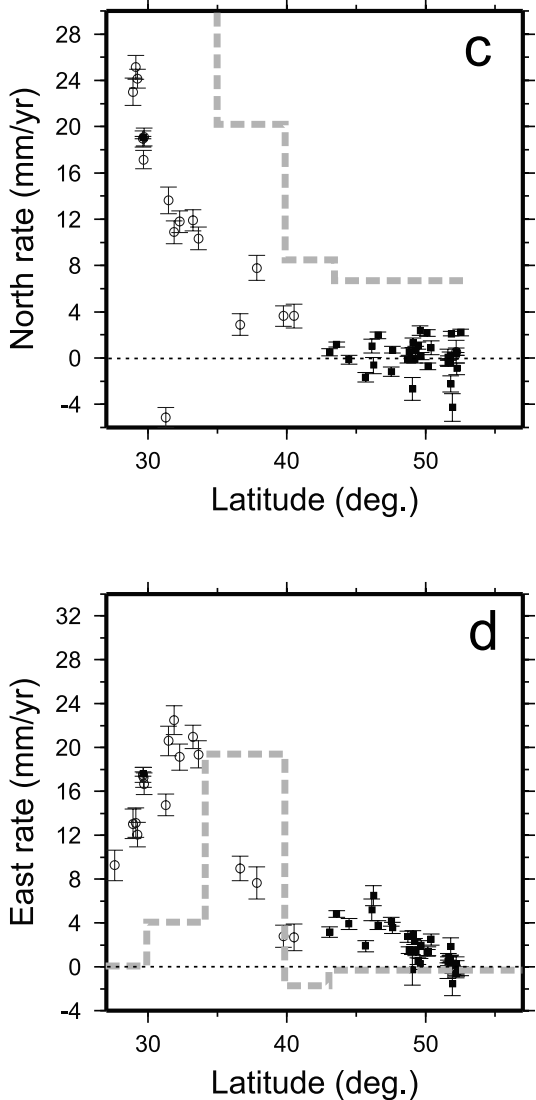

E-Mongolia profile
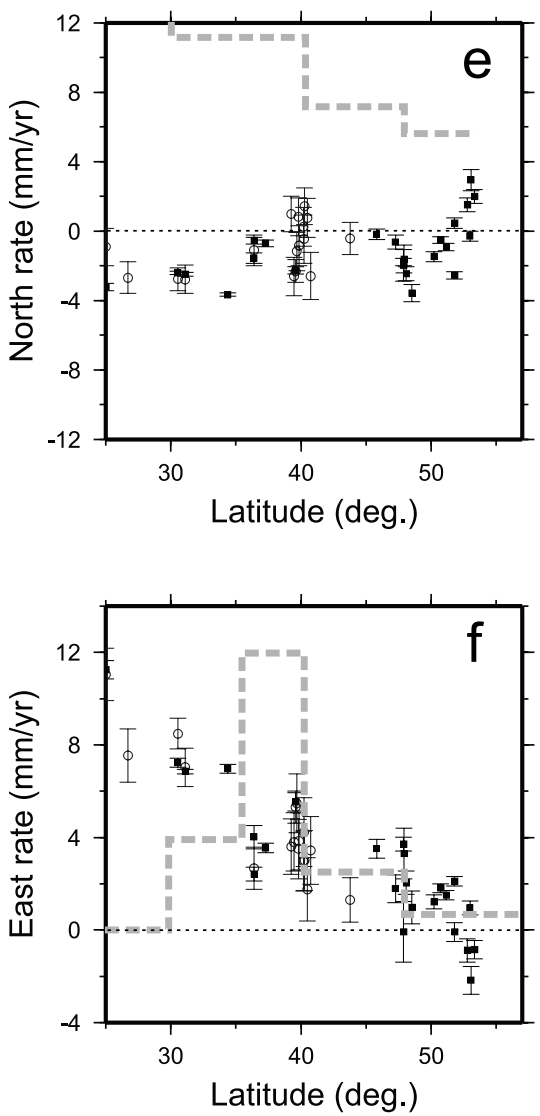

Figure 8. Velocity profiles across Asia, based on the combination of the Baikal-Mongolia data set presented above (solid symbols) and the GPS results of Wang et al. [2001] (open symbols). The thick dashed gray line shows the velocity solution of Peltzer and Saucier [1996]. The location and width of these profiles are shown on Figure 4.

significant net force because of the large N-S extent of the Pacific subductions. However, in spite of the possibility that forces and processes other than the India-Eurasia collision participate in driving continental deformation in Asia, their magnitude and relative importance remain currently unknown.

[27] An important additional observation for the extrusion debate was recently reported by Wang et al. [2001]. They find a low shortening rate across the eastern border of the Tibetan Plateau $\left(<3 \mathrm{~mm} \mathrm{yr}^{-1}\right.$, also reported by Shen et al. [1999]) but 5-11 $\mathrm{mm} \mathrm{yr}^{-1}$ of far-field convergence between eastern Tibet and south China. They interpret this apparent inconsistency as an indication that Tibet is not "pushing" south China eastward. In their interpretation, the Tibetan crust is rather rotating clockwise around the east Himalayan syntaxis resulting in the southward velocities observed in southwestern China, and the eastward motion of south China is occurring independently of the motion of Tibet. Similarly, the eastward to southeastward velocities in Mongolia and north China with respect to Eurasia also suggest that crustal motions and deformations in northern Asia occur independently of the N-S shortening observed further south from the Himalayas to the Tien Shan. If the eastward motion of south and north China is not solely driven by India-Eurasia collision, then the driving force for the counterclockwise rotation of north and south China as a quasi-rigid block may be sought in the dynamics of the subduction zones bordering Asia to the east.

\subsection{Current Motion of North and South China}

[28] One of the implications of kinematic models of Asia is a significant differential motion between north and south China, assumed to be accommodated by left-lateral slip on the Qinling Shan and Ordos graben faults. On the contrary, dynamic models imply no or very little differential motion between north and south China, as a large part of the deformation is accommodated by crustal thickening rather than lateral block motions.

[29] We test the hypothesis of a differential motion between north and south China by estimating rotation parameters using the best determined sites located on the north China block: XIAN, BJFS, ULA1, ULAN, CHOI. The resulting parameters and associated $\chi^{2}$ are given in Table 3. We do not include continuous sites in Korea because of the proximity of the strongly coupled subduction of the Pacific Sea plate under southern Japan, associated with elastic strain accumulation in the upper plate reaching far inland [Mazzotti et al., 2000]. In a second step, we add sites WUHN and SHAO, located on the south China block, 
Table 3. Rotation Parameters for North and South China With Respect to Eurasia

\begin{tabular}{lcccr}
\hline \multicolumn{1}{c}{ Sites Used in Estimation } & Latitude, deg & Longitude, deg & Rate, deg $\mathrm{Myr}^{-1}$ & $\chi^{2}$ \\
\hline XIAN, BJFS, ULA1, CHOI, ULAN & $58.360 \pm 6.11$ & $130.968 \pm-1.91$ & $0.1430 \pm 0.0289$ & 120.049 \\
Same plus SHAO, WUHN & $61.209 \pm 5.36$ & $139.089 \pm-1.31$ & $0.1193 \pm 0.0132$ & 172.618 \\
Same plus GUIV, QUAN & $60.578 \pm 4.61$ & $136.746 \pm-1.12$ & $0.1229 \pm 0.0124$ & 209.230 \\
\hline
\end{tabular}

and estimate new rotation parameters for the new site subset (Table 3 ). We then use an $F$ ratio test to compare the results of the two least squares estimations. We find that the two estimates are similar at the $67 \%$ confidence level. Adding the two best determined campaign sites on the south China block to the estimation (GUIV and QUAN) strengthens this result with a $77 \% F$ ratio confidence level (Table 3 ). Figure 9 shows the residual velocities in a model that includes XIAN, BJFS, ULA1, ULAN, CHOI, SHAO, and WUHN. Maximum residuals are $1.6 \mathrm{~mm} \mathrm{yr}^{-1}$ at ULA1 and CHOI. Residual velocities at the two best determined campaign sites in south China, GUIY and QUAN, are 0.9 and $2.2 \mathrm{~mm} \mathrm{yr}^{-1}$, respectively.

[30] Clearly, this analysis is based on a limited amount of data and needs to be confirmed with additional GPS in north and south China. Nevertheless, it indicates that north and south China can be modeled as a single rigid block at the $2 \mathrm{~mm} \mathrm{yr}^{-1}$ level, rotating counterclockwise around a pole located north of the Stanovoy fault zone. The Stanovoy fault zone is close to a small circle about that pole. The rotation found above implies a general left-lateral motion along that fault zone, with an additional extensional component in its western part, and an additional compressional component in its eastern part, consistent with seismotectonic data [Fujita et al., 1992, 1996]. Incidentally, this new GPS data set rules out Heki et al.'s [1999] definition of the Amurian plate that predicts eastward velocities of $\sim 10 \mathrm{~mm} \mathrm{yr}^{-1}$ in Mongolia and northern China, not observed in the data.

[31] If this quasi-rigid rotation of north and south China is correct, then slip rates on the Qinling Shan fault and the faults bordering the Ordos grabens to the north should not exceed $2 \mathrm{~mm} \mathrm{yr}^{-1}$, unless local block rotation are involved. This observation is not consistent with extrusion models, which predict at least $5 \mathrm{~mm} \mathrm{yr}^{-1}$ of differential motion between north and south China [Peltzer et al., 1988; Avouac and Tapponnier, 1993; Peltzer and Saucier, 1996].

\section{Conclusions}

[32] GPS measurements of horizontal surface motions in the Baikal rift zone and Mongolia show that $\sim 15 \%$ of the India-Eurasia convergence is accommodated north of the

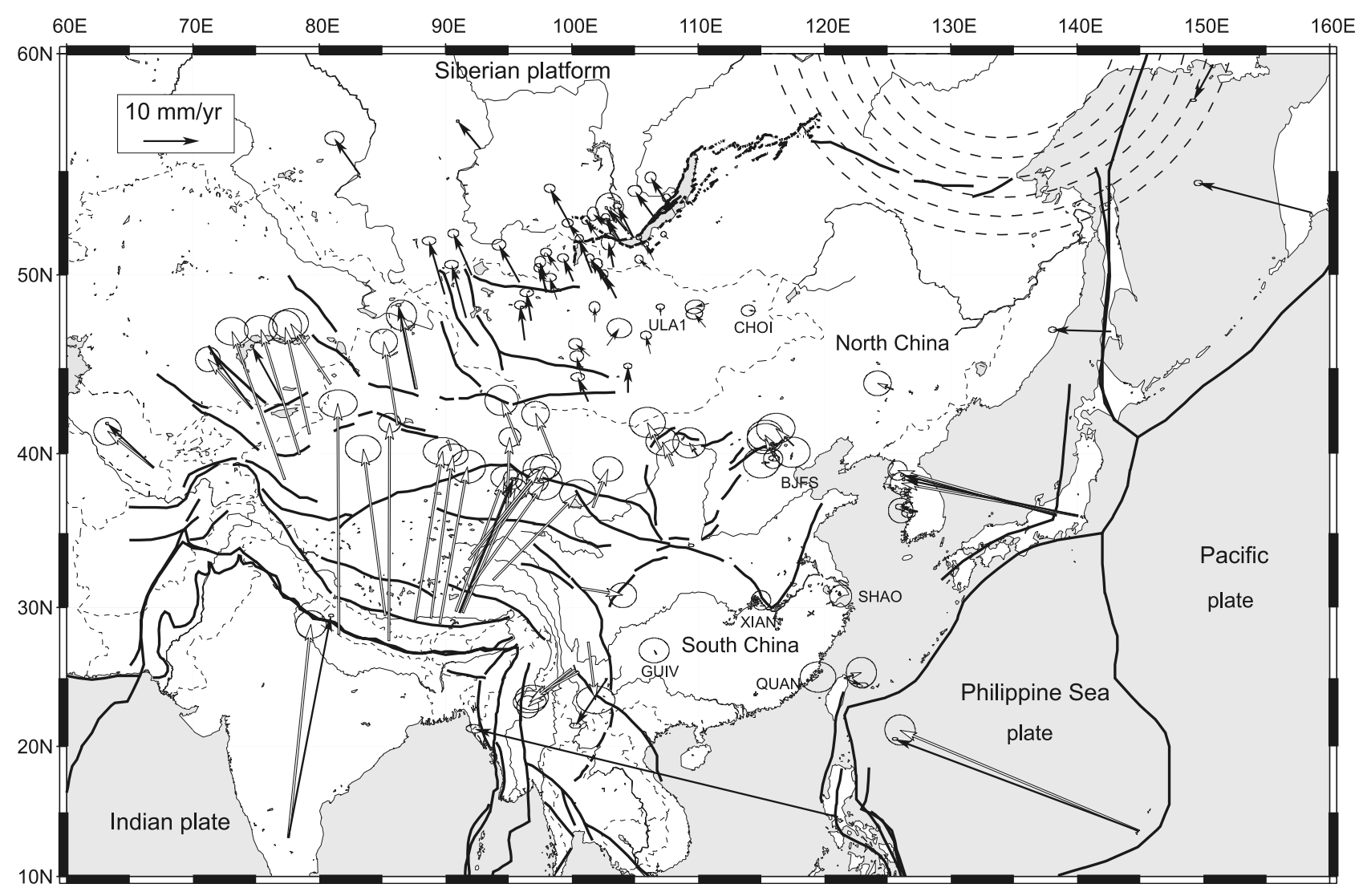

Figure 9. GPS-derived velocities with respect to east China. Black arrows, our solution; grey arrows, Wang et al.'s [2001] solution after transformation into ITRF2000 and rotation into a Eurasia-fixed frame (explanation in text). Ellipses are 95\% confidence. Dashed lines are small circles around the rotation pole of east China with respect to Eurasia. 
Tien Shan, by N-S shortening combined with dextral shear in the Mongolian Altay, by eastward displacements along major left-lateral strike-slip faults in central and eastern Mongolia. The combination of our data set with GPS velocity field for China of Wang et al. [2001] shows a counterclockwise rotation of north and south China as a quasi-rigid block around a pole north of the Stanovoy belt. A comparison with the extrusion model of Peltzer and Saucier [1996] shows, in general, a fair agreement with the GPS-derived velocities, with, however, a few notable misfits. In particular, the EW left-lateral shear regime in central Mongolia, the SE velocity of Amuria/north China, and the $<2 \mathrm{~mm} \mathrm{yr}^{-1}$ differential motion between north and south China observed in the GPS data are not reproduced by the model.

[33] Our results point to a model where the continued convergence between India and Eurasia would provide the driving force for crustal shortening and thickening, whereas the state of stress along the subduction zones bounding Asia to the east, together with gravitational potential energy gradients, would control the amount of eastward motion of north and south China as a quasi-rigid lithospheric block.

[34] Clearly, the amount and quality of geodetic results in Asia is raising a number of fundamental questions that are not resolved by any of the deformation models of Asia proposed to date. Together with other strain indicators, such as earthquakes and fault slip rates from geological studies, the GPS velocity field described above provides an extensive and objective data set to quantitatively validate a new generation of deformation models for Asia.

[35] Acknowledgments. This work was initiated in 1994 by a collaboration between the Institute of the Earth Crust, Siberian Branch of the Russian Academy of Science, Irkutsk, and the CNRS. This collaboration was extended in 1997 to the Research Center for Astronomy and Geophysics, Ulan Bator, Mongolia. We are particularly grateful to Academician N. A. Logatchev, former director of the Institute of the Earth's Crust, whose support allowed us to initiate this work. We also thank B. Bekhtur, director of the Research Center for Astronomy and Geophysics, for its continuous support. We thank all the field operators who participated in the acquisition of the GPS data through the years and to the staff of the Institute of the Earth's Crust and of the Research Center for Astronomy and Geophysics for the efficient support they were able to provide. We thank M. Saandar (MonMap Engineering Services Co. Ltd) and G. Enkhbayar (Mongolia State Agency for Geodesy and Cartography) for their contribution to this work. We acknowledge the contribution of the earlier work by Olivia Lesne, who has been a significant contributor to the success of this research project. We thank Paul Tregoning for insightful discussions on the reference frame issues and on the definition of the "Amurian plate" as well as Tim Dixon, Nancy King, Ken Hudnut, and Associate Editor Joan Gomberg, whose comments help improve the quality of this paper. This research was supported by the INSU-CNRS ("Tectoscope-Positionnement 1994," "Intérieur de la Terre 1997 and 2000"), the French Ministry for Foreign Affairs and the CNRS through a PICS program ("Programme International de Coopération Scientifique"), the French Ministry for Education and Research ("DSPT3") and the French Ministry of Foreign Affairs ("Enveloppe Echanges Scientifiques"), the INTAS European agency (grants 962194 and 97-30874), NATO (grant LG961302), the Siberian Branch of the Russian Academy of Sciences.

\section{References}

Abdrakhmatov, K. Y., et al., Relatively recent construction of the Tien Shan inferred from GPS measurements of present-day crustal deformation rates, Nature, 384, 450-453, 1996.

Altamimi, Z., P. Sillard, and C. Boucher, ITRF2000: A new release of the International Terrestrial Reference Frame for earth science applications, J. Geophys. Res., 107(B10), 2214, doi:10.1029/2001JB000561, 2002.

Argand, E., La Tectonique de l'Asie, Congres Geologique International, Comptes Rendus de la XIII Session, Belgique, 1922, 596 pp., Premier Fascicule, Brussels, 1924.
Arjannikova, S. G., Paleoseismodislocations in the Ottugtaigino-Azassky fault zone (eastern Tuva) (in Russian), Russ. Geol. Geophys., 41, 15011510, 2000.

Arjannikova, S. G., C. Larroque, J.-F. Ritz, J. Deverchere, J.-F. Stephan, S. Arjannikov, and V. San'kov, Geometry and kinematics of recent and active deformation at the southwesternmost Baikal rift zone (MongoliaSiberia) from neotectonic and space imagery constraints, Terra Nova, in press, 2003.

Avouac, J. P., and P. Tapponnier, Kinematic model of deformation in central Asia, Geophys. Res. Lett., 20, 895-898, 1993.

Baljinnyam, I., et al., Ruptures of major earthquakes and active deformation in Mongolia and its surroundings, Mem. Geol. Soc. Am., 181, 62 pp., 1993.

Bayasgalan, A., Active tectonics of Mongolia, Ph.D. thesis, 180 pp., Trinity Coll., Cambridge, England, 1999.

Bayasgalan, A., J. Jackson, J. F. Ritz, and S. Carretier, Field examples of strike-slip fault terminations in Mongolia and their tectonic significance, Tectonics, 18, 394-411, 1999.

Bendick, R., R. Bilham, J. Freymueller, K. Larson, and G. Yink, Geodetic evidence for a low slip rate in the Altyn Tagh fault system, Nature, 404, $69-72,2000$.

Bilham, R., K. Larson, J. Freymueller, and Project Idylhim Members, GPS measurements of present-day convergence across the Nepal Himalaya, Nature, 386, 61-64, 1997.

Calais, E., and S. Amarjargal, New constraints on current deformation in Asia from continuous GPS measurements at Ulan Baatar, Mongolia, Geophys. Res. Lett., 27, 1527-1531, 2000.

Calais, E., O. Lesne, J. Deverchre, V. Sankov, A. Lukhnev, A. Miroshnitchenko, V. Buddo, K. Levi, V. Zalutzky, and Y. Bashkuev, GPS measurements of crustal deformation in the Baikal rift zone, Siberia, Geophys. Res. Lett., 25, 4003-4006, 1998.

Calais, E., M. Vergnolle, J. Deverchre, V. Sankov, A. Lukhnev, and S. Amarjargal, Are postseismic effect of the $M=8.4$ Bolnay earthquake (July 12, 1905) still influencing GPS velocities in the Mongolia-Baikal area?, Geophys. J. Int., 148, 1-12, 2002.

Chen, Z., B. C. Burchfiel, Y. Liu, R. W. King, L. H. Royden, W. Tang, E. Wang, J. Zhao, and X. Zhang, GPS measurements from eastern Tibet and their implications for India/Eurasia intercontinental deformation, J. Geophys. Res., 105, 16,215-16,227, 2000.

Cobbold, P., and P. Davy, Indentation tectonics in nature and experiment, 2. Central Asia, Bull. Geol. Inst. Uppsala, 14, 143-161, 1988.

Cook, D. B., K. Fujita, and C. A. McMullen, Present day plate interactions in northeast Asia: North American, Eurasian, and Okhotsk plates, J. Geodyn., 6, 33-51, 1986.

Cunningham, W. D., B. F. Windley, D. Dorjnamjaa, G. Badamgarov, and M. Saandar, A structural transect across the Mongolian Altay: Active transpressional mountain building in central Asia, Tectonics, 15, 142156, 1996 a.

Cunningham, W. D., B. F. Windley, D. Dorjnamjaa, G. Badamgarov, and M. Saandar, Late Cenozoic transpression in southwestern Mongolia and the Gobi Altay-Tien Shan connection, Earth Planet. Sci. Lett., 140, 67$81,1996 \mathrm{~b}$.

Delouis, B., J. Deverchere, V. Melnikova, N. Radziminovitch, L. Loncke, C. Larroque, and V. San'Kov, A reappraisal of the source of the $1950\left(M_{w}\right.$ 6.9) Mondy earthquake, Siberia, and its relevance to the present-day strain pattern at the southwestern end of the Baikal Rift zone, Terra Nova, 14(6), 491-500, 2002.

Delvaux, D., R. Moeys, G. Stapel, C. Petit, K. Levi, A. Miroshnichenko, V. Ruzhich, and V. San'kov, Paleostress reconstructions and geodynamics of the Baikal region, central Asia, II, Cenozoic rifting, Tectonophysics, 282, 1-38, 1997.

Déverchère, J., F. Houdry, N. V. Solonenko, A. V. Solonenko, and V. San'kov, Seismicity, active faults and stress field of the North Muya region, Baikal rift: New insights on the rheology of extended continental lithosphere, J. Geophys. Res., 98, 19,895-19,912, 1993.

Déverchère, J., C. Petit, N. Gileva, N. Radziminovitch, V. Melnikova, and V. San'kov, Depth distribution of earthquakes in the Baikal rift system and its implications for the rheology of the lithosphere, Geophys. J. Int., 146, 714-730, 2001.

England, P. E., and G. Houseman, Finite strain calculations of continental deformation: 2. Comparison with the India-Eurasia collision zone, J. Geophys. Res., 91, 3664-3676, 1986.

England, P., and P. Molnar, Active deformation of Asia: From kinematics to dynamics, Science, 278, 647-650, 1997.

Flesch, L. M., A. J. Haines, and W. E. Holt, The dynamics of the IndiaEurasia collision zone, J. Geophys. Res., 106, 16,435-16,460, 2001.

Fujita, K., S. A. Riegel, C. A. McMullen, D. R. Olson, D. B. Cook, B. M. Kozmin, and V. S. Imaev, Characterization of focal mechanisms in northeast Siberia, Seismol. Res. Lett., 63, 27, 1992.

Fujita, K., F. W. Cambray, K. G. Mackey, B. M. Kozmin, V. S. Imaev, B. P. Vazhenin, V. N. Kovalev, W. Y. Chung, and H. Gao, Seismotectonics of 
eastern Russia: From Baikal to Chukotka, Geol. Soc. Am. Abstr. Programs, 27(5), 19, 1995.

Gordon, R. G., D. F. Argus, and M. B. Heflin, Revised estimate of the angular velocity of India relative to Eurasia, Eos Trans. AGU, 80(46), Fall Meet. Suppl., F273, 1999.

Heki, K., S. Miyazaki, H. Takahashi, M. Kasahara, F. Kimata, S. Miura N. F. Vasilenko, A. Ivashchenko, and K. D. An, The Amurian plate motion and current plate kinematics in eastern Asia, J. Geophys. Res., 104, 29,147-29,155, 1999.

Herring, T. A., J. L. Davis, and I. I. Shapiro, Geodesy by radio interferometry: The application of Kalman filtering to the analysis of very long baseline interferometry data, J. Geophys. Res., 95, 12,561-12,581, 1990.

Houseman, G., and P. E. England, Finite strain calculations of continental deformation: Method and general results for convergent zones, J. Geophys. Res., 91, 3651-3663, 1986.

Houseman, G., and P. England, Crustal thickening versus lateral expulsion in the India-Asia continental collision, J. Geophys. Res., 98, 12,233$12,249,1993$.

Khilko, S. D., R. A. Kurushin, V. M. Kotchetkov, L. A. Misharina, V. I. Melnikova, N. A. Gileva, S. V. Lastochkin, I. Baljinnyam, and D. Monhoo, Earthquakes and the base of the seismogenic zoning of Mongolia (in Russian), in The Joint Soviet-Mongolian Research Geological Scientific Expedition, vol. 41, 225 pp., Nauka, Novosibirsk, Russia, 1985.

King, R. W., F. Shen, B. C. Burchfield, L. Royden, E. Wang, Z. Chen, Y. Liu, X. Zhang, J. Zhao, and Y. Li, Geodetic measurement of crustal motion in southwest China, Geology, 25, 179-182, 1997.

Kogan, M. G., et al., Geodetic constraints on thr rigidity and relative motion of Eurasia and North America, Geophys. Res. Lett., 27, 2041-2044, 2000

Kong, X., and P. Bird, Neotectonics of Asia: thin-shell finite-element models with faults, in The Tectonic Evolution of Asia, edited by A. Yin and T. M. Harrison, pp. 19-34, Cambridge Univ. Press, New York, 1996.

Kurushin, R. A., A. Bayasgalan, M. Olziybat, B. Enhtuvshin, P. Molnar, Ch. Bayarsayhan, K. Hudnut, and J. Lin, The surface rupture of the 1957 Gobi-Altay, Mongolia, earthquake, Spec. Pap. Geol. Soc. Am., 320 , 143 pp., 1997.

Larson, K., R. Brgmann, R. Bilham, and J. Freymueller, Kinematics of the India-Eurasia collision zone from GPS measurements, J. Geophys. Res., 104, 1077-1093, 1999

Mazzotti, S., X. LePichon, P. Henry, and S. Miyazaki, Full interseismic locking of the Nankai and Japan-West Kuril subduction zones: An analysis of uniform elastic strain accumulation in Japan constrained by permanent GPS, J. Geophys. Res., 105, 13,159-13,177, 2000.

Milne, G. A., J. L. Davis, J. X. Mitrovica, H.-G. Scherneck, J. M. Johansson, M. Vermeer, and H. Koivula, Space-geodetic constraints on glacial isostatic adjustment in Fennoscandia, Science, 291, 2381-2385, 2001.

Molnar, P., and Q. Deng, Faulting associated with large earthquakes and the average of deformation in central and eastern Asia, J. Geophys. Res., 89 6203-6227, 1984

Molnar, P., and S. Ghose, Seismic moments of major earthquakes and the rate of shortening across the Tien Shan, Geophys. Res. Lett., 27, $2377-$ 2380, 2000

Molnar, P., and J. M. Gipson, A bound on the rheology of continental lithosphere using very long baseline interferometry: The velocity of south China with respect to Eurasia, J. Geophys. Res., 101, 545-553, 1996.

Molnar, P., B. C. Burchfield, Z. Zhao, K. Liang, S. Wang, and M. Huang, Geologic evolution of northern Tibet: Results of an expedition to Ulugh Muztagh, Science, 235, 299-305, 1987.

Okal, E., The July 9 and 23, 1905, Mongolian earthquakes: A surface wave investigation, Earth Planet. Sci. Lett., 34, 326-331, 1977.

Parfeevets, A. V., V. A. Sankov, A. I. Miroshnitchenko, and A. V. Lukhnev, Crustal state of stress evolution of Mongolia-Baikal mobile belt (in Russian), Tikhookeanskaya Geol., 21, 14-28, 2002.

Paul, J., et al., The motion and active deformation of India, Geophys. Res. Lett., 28, 647-650, 2001.

Peltzer, G., and F. Saucier, Present-day kinematics of Asia derived from geologic fault rates, J. Geophys. Res., 101, 27,943-27,956, 1996.

Peltzer, G., and P. Tapponnier, Formation and evolution of strike-slip faults, rifts, and basins during the India-Asia collision: An experimental approach, J. Geophys. Res., 93, 15,085-15,117, 1988.
Prentice, C. S., K. J. Kendrick, K. Berryman, A. Bayasgalan, J. F. Ritz, and J. Q. Spencer, Prehistoric ruptures of the Gurvan Bulag fault, Gobi Altay, Mongolia, J. Geophys. Res., 107(B12), 2321, doi:10.1029/ 2001JB000803, 2002.

Ritz, J. F., E. T. Brown, D. L. Bourlès, H. Philip, A. Schlupp, G. M. Raisbeck, F. Yiou, and B. Enkhtuvshin, Slip rates along active faults estimated with cosmic-ray-exposure dates: Application to the Bogd fault, Gobi-Altay, Mongolia, Geology, 23, 1019-1022, 1995

Ritz, J.-F., et al., Late Pleistocene to Holocene slip rates for the Gurvan Bulag thrust fault (Gobi-Altay, Mongolia) estimated with $10 \mathrm{Be}$ dates, J. Geophys. Res., 108(B3), 2162, doi:10.1029/2001JB000553, 2003.

San'kov, V. A., et al., On the estimation of rates of horizontal Earth crust movements of the Baikal rift system on the basis of GPS geodesy and seismotectonics (in Russian), in Tectonophysics Today, edited by V. N. Strakhov and Y. G. Leonov, pp. 120-128, United Inst. of the Phys. of the Earth, Russ. Acad. of Sci., Moscow, 2002

Savage, J. C., Strain accumulation in western United States, Annu. Rev. Earth Planet Sci., 368, 11-43, 1983.

Schlupp, A., Néotectonique de la Mongolie Occidentale analysée à partir de données de terrain, sismologiques et satellitaires, Ph.D. thesis, Univ. Louis Pasteur, Strasbourg, France, 1997.

Sella, G. F., T. H. Dixon, and A. Mao, REVEL: A model for Recent plate velocities from space geodesy, J. Geophys. Res., 107(B4), 2081, doi:10.1029/2000JB000033, 2002.

Shen, Z. K., C. Zhao, A. Yin, Y. Li, D. Jackson, P. Fang, and D. Dong, Contemporary crustal deformation in east Asia constrained by Global Positionning System measurements, J. Geophys. Res., 105, 5721 5734, 2000.

Solonenko, A. V., N. V. Solonenko, V. I. Melnikova, and E. A. Shteiman, Seismicity and the stress field of the Baikal seismic zone, Bull. Cent. Rech. Explor. Prod., 21, 207-231, 1997.

Tapponnier, P., and P. Molnar, Active faulting and cenozoic tectonics of China, J. Geophys. Res., 82, 2905-2930, 1977.

Tapponnier, P., and P. Molnar, Active faulting and Cenozoic tectonics of the Tien Shan, Mongolia and Baikal regions, J. Geophys. Res., 84, 34253459, 1979.

Tapponnier, P., G. Peltzer, A. Y. Le Dain, R. Armijo, and P. Cobbold, Propagating extrusion tectonics in Asia: New insights from simple experiments with plasticine, Geology, 10, 611-616, 1982.

Vergnolle, M., F. Pollitz, and E. Calais, Constraints on the viscosity of the continental crust and mantle from GPS measurements and postseismic deformation models in western Mongolia, J. Geophys. Res., 108, doi:10.1029/2002JB002374, in press, 2003.

Vertlib, M. B., Determination of focal depths by the composite method for some regions of Pribaikalie (in Russian), in Seismic Investigations in East Siberia, edited by V. A. Rogozhina, pp. 82-88, Nauka, Moscow, 1981. Vilotte, J. P., M. Daignieres, and R. Madariaga, Numerical modeling of intraplate deformation: Simple mehcnical models of continental collision, J. Geophys. Res., 87, 19,709-19,728, 1982.

Wang, Q., et al., Present-day crustal deformation in China constrained by Global Positioning System measurements, Science, 294, 574-577, 2001.

S. Amarjargal, Research Center for Astronomy and Geophysics, P.O. Box 788, Ulaanbaatar 210613, Mongolia. (amar@csg.mn)

E. Calais, Department of Earth and Atmospheric Sciences, Purdue University, CIVIL 1397, West Lafayette, IN 47907-1397, USA. (ecalais@ purdue.edu)

J. Déverchère, UMR CNRS 6538, University Bretagne Occidentale, Technopole Brest-Iroise, Place Nicolas Copernic, F-29280 Plouzané, France. (jacdev@univ-brest.fr)

A. Lukhnev, A. Miroshnitchenko, and V. San'kov, Institute of the Earth's Crust, Siberian Branch of the Russian Academy of Sciences, 128 Lermontova Street, 664033 Irkutsk, Russia. (loukhnev@crust.irk.ru; miroshni@crust.irk.ru; sankov@crust.irk.ru)

M. Vergnolle, UMR CNRS 6526, Université de Nice, 250 Rue A. Einstein, F-06560 Valbonne, France. (vergno@geoazur.unice.fr) 